\title{
Evaluation of different pig production systems including economic, welfare and environmental aspects
}

\begin{abstract}
Summary
The aim of the study is to evaluate different production systems in pig farming including economic, animal welfare and environmental aspects with computer simulation. The computer model considers a vertically integrated system with farrowing, weaning, fattening and slaughtering stage as well as the transportation of pigs between theses stages. Housing systems were distinguished in individual and group housing with partly/fully slatted flooring or straw. Housing conditions were scaled to animal welfare in a decreasing order from straw, social contact to movement. Environmental issues were measured by nitrogen $(\mathrm{N})$ and phosphorous (P) excretion.

With standard pork production (slatted floors, individual housing of sows, small groups of fattening pigs) the cost per fattening pig accounted for $€$ 131.72, N- and P-excretion were 7.1 and $1.2 \mathrm{~kg}$ per head. Group housing for gestating sows (slatted floor) and a higher number of fattening pigs per group increased welfare scoring by 25\%. Cost, N- and P-excretion were reduced by 3.5, 5.1 and 5.2\%. Group housing of sows during lactation, mating and gestation (with prolonged lactation length 5 weeks; welfare scoring $100 \%$ ) and straw in each stage raised production cost by $24.6 \%$ (€ 32.31), $\mathrm{N}$ - and P-excretion were enhanced to $8.0 \mathrm{~kg}(12.7 \%)$ and $1.3 \mathrm{~kg}$ (10.5\%) per head.
\end{abstract}

Key Words: pig, production systems, economy, welfare, environment

\section{Zusammenfassung}

Titel der Arbeit: Vergleich verschiedener Produktionssysteme beim Schwein hinsichtlich Ökonomie, Tiergerechtheit und Umweltwirkung

Der vorliegende Beitrag vergleicht verschiedene Produktionssysteme beim Schwein hinsichtlich der Ökonomie, der Tiergerechtheit sowie den N- und P-Ausscheidungen mit einer Computersimulation. Das Simulationsmodell generiert ein vertikal integriertes Produktionssystem mit den Stufen Ferkelerzeugung, Aufzucht, Mast und Schlachthof und berücksichtigt ferner die Transporte zwischen diesen Stufen. Die Haltungsverfahren wurden in Einzel- und Gruppenhaltung (Klein-/Großgruppen) auf Voll-/Teilspaltenboden oder Stroh differenziert. Die Bewertung der Haltungsverfahren bezüglich der Tiergerechtheit basiert auf Ergebnissen der operanten Konditionierung. Die Komponenten Stroh, soziale Kontakte und Bewegung wurden in abnehmender Rangfolge gewichtet. Die Einschätzung der Umweltwirkung orientierte sich an den N- und P-Ausscheidungen.

In der Ausgangssituation (Einzelhaltung - Sauen, Kleingruppen - Aufzucht, Mast; Vollspaltenboden) betrugen die Produktionskosten $€ 131,72$ je Mastschwein, die N- und P-Ausscheidungen 7,1 und 1,2 kg. Gruppenhaltung der tragenden Sauen und die Erhöhung der Anzahl Mastschweine je Gruppe steigerte die Tiergerechtheit um 25\%, die Kosten sowie die N- und P-Ausscheidungen reduzierten sich um 3,5, 5,1 und 5,2\%. Gruppenhaltung in allen Reproduktionszyklen (mit verlängerter Säugezeit von fünf Wochen) und Stroh als Einstreu erhöhten die Produktionskosten um 24,6\% (€ 32,31), die N- und P-Ausscheidungen stiegen auf $8 \mathrm{~kg}(12,7 \%)$ und 1,3 kg $(10,5 \%)$ je Mastschwein.

Schlüsselwörter: Schwein, Produktionssysteme, Ökonomie, Tiergerechtheit, Umwelt

1. Introduction

In time of BSE, foot and mouth disease and classical swine fever public concern about quality of animal products and the way of production including food safety and animal welfare has grown. The main focus in public debates about the way in which 
farm animals live concerns the housing conditions. This context is reflected by the legislation and regulations by the EU and the national administrative involvement. These regulations have a great impact on pig production and will modify the feature of pig facilities and management tools which influence pig production cost. The present paper elaborates different production systems in pig farming concerning economic, welfare and environmental issues. The analysis was performed with a computer model which simulates a vertical integrated pork production chain. Thus the model estimates the effects of different housing systems on the production cost, welfare and the excretion of Nitrogen and Phosphorous at various stages of a pork production chain.

2. Material and Methods

2.1 General Concept

In general the simulation model includes an integrated production chain with vertical linkages between the four stages: the farrowing, rearing, fattening and slaughter of pigs. In the farrowing stage feeder pigs are produced, which are passed onto the fattening stage at a live weight of $28 \mathrm{~kg}$. Animals are slaughtered at a live weight of $115 \mathrm{~kg}$. Carcasses are marketed as a whole or processed further to valuable cuts (e.g. ham, cutlet, belly).

The model is based on a deterministic approach using fixed probability distributions (e.g., different culling rates for sows within cycle; pathological lesions for slaughterpigs). Three types of parameters (in-, output) were distinguished for each stage: biological/management variables, technical and economic factors. Biological factors imply parameters such as litter size born alive, days open, daily gain, feed intake and also management aspects such as time to weaning. Technical factors primarily include housing systems for lactating, mating and gestation sows, weaned and fattening pigs.

\subsection{Technical factors}

The model regards alternate housing conditions for sows, feeder and fattening pigs (s. Table 1). In the base situation lactating sows were kept in farrowing crates with fully slatted flooring. Mating and gestating sows were housed individually without access to straw. Sows were fed automatically, saving labour time using different diets for lactation and mating/gestation. Feeder and fattening pigs were kept in small groups with fully slatted flooring. Fattening pigs were fed automatically using 'one phase feeding'.

Alternate systems was chosen according to the current distributions and trend (HENDRIKS, et al., 1998) as well as available information about performance and cost and future legislation in the EU. For lactating sows alternative systems were crates and integrated group housing systems with straw (GERTKEN, 1992). Loose or partly loose housing systems within stalls during lactation was neglected due to missing data about cost and performance level. For mating and gestating sows alternate systems based on group housing with and without straw. Feeding of sows was performed with an electronic controlled feeding station. Similar housing conditions were used for feeder and fattening pigs (large groups with slatted flooring or deep litter). In addition partly slatted flooring and systems with restricted straw were included because these systems are becoming increasingly popular. 
Table 1

Alternative housing-systems for different stages of the production chain (Alternative Haltungsverfahren für die verschiedenen Stufen der Produktionskette)

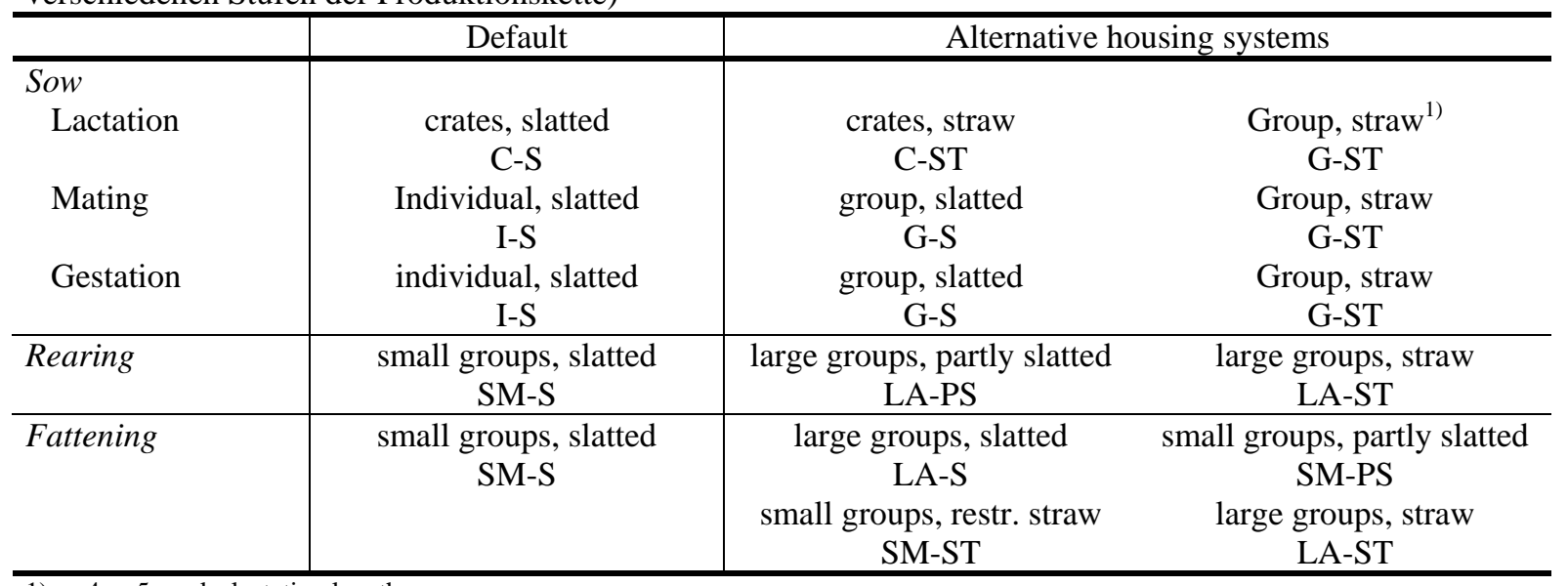

1) 4 or 5 weeks lactation length

\section{$2.3 \quad$ Biological/management input values}

Major input values for each stage used in the default and alternative situations are summarised in Table 2. Default values are determined using results from official consulting services (CLAUS et al., 2000; VIT, 2000). Parameters (biological/economical) for the alternative housing conditions base on literary review (KTBL, 1999; KEMPKES, 1997; WEBER, 1997; DE BAEY-ERNSTEN and ACHILLES, 1997; DE BAEY-ENSTEIN, 1997; DE BAEY-ERNSTEIN, 1996; SCHÄFER-MÜLLER und STAMER, 1996; ELLERSIEK, 1999a,b; GOURMELEN et al., 2000; RANTZER und SVENDSEN, 2001a ,b; WOLTER et al., 2001; GERTKEN, 1992; JENSEN et al., 2000; TURNER and EDWARDS, 2000; HÖGES and ACKERMANN, 1998).

Table 2

Major biological / management factors for different stages and production systems of the production chain (Biologische Parameter für die verschiedenen Stufen und Haltungsverfahren der Produktionskette)

\begin{tabular}{l|r|l}
\hline Stage / System & Default & \multicolumn{1}{|c}{ Alternative housing systems } \\
\hline Farrowing, Mating/Gestation & & \\
Lactation length (day) & 28 & \\
Interval weaning at first estrus ${ }^{3)}$ & $8 / 10$ & G-S, G-ST: 2/2 \\
Rebreeding (\%) $\quad 14$ & G-S, G-ST: 2.8 \\
Abort (\%) & 3 & \\
Piglets born alive ${ }^{2)}$ & 10.2 & G-S, G-ST: -0.2 \\
Preweaning mortality & 16.3 & G-ST: 5.0 \\
\hline Rearing & & \\
Daily gain (g) & 420 & LA-PS,LA-ST: -20 \\
Postweaning mortality (\%) & 1.0 & LA-ST: 1.0 \\
Weight at which feeder pigs are sold (kg) & 28 & \\
\hline Fattening & & \\
Daily gain (g) & 720 & LA-S: 36; LA-ST: -30 \\
Mortality (\%) & 3 & LA-S: -0.3 \\
Mean live weight at slaughter (kg) & 115 & \\
Dressing percentage (\%) & 79 & \\
Lean meat percentage & 56.8 & LA-S: -0.5; LA-ST: -1.8 \\
\hline 1) Multiparous, primaparous sows & & \\
2) averaged over ten litter & &
\end{tabular}


The model starts with the generation of sow performance. Based on a gestation period of 115 days, lactation length 28 (default) and 8 or 10 days from weaning to first breeding (different for prima- and multiparous sows) the production cycle was at least 150 days. On average, the production cycle is longer due to reproduction failure (e.g. rebreeding, abortion). Group housing for mating sows increased interval weaning to estrus and rebreeding because management tools are demanding. Litter size and piglet mortality were simulated over ten litters with non-linear pattern for litter size born alive and piglet mortality (DE VRIES, 1989; BRANDT, 1984). An average of 10.2 piglets were born alive and piglet mortality amounted to 16.3. In integrated group housing system piglet mortality was enhanced by 5\% (GERTKEN, 1992). Culling percentage of sows differed between litters (DE VRIES, 1989; KRIETER, 1994). Culled sows were replaced by gilts which were integrated into the herd with 180 days. Average lifetime was calculated with 5.5 litters per sow.

Growth performance is of major importance with respect to feed efficiency and production cycles realised per year. The growth performance of feeder and fattening pigs was described using the Gompertz function (DOURMAD et al., 1992; KRIETER and KALM, 1989) with the formula $\mathrm{BW}_{\mathrm{t}}=\mathrm{K} *\left(\mathrm{BW}_{\mathrm{i}} / \mathrm{K}\right) \exp (-\mathrm{I} * \mathrm{t})$ with $\mathrm{BW}_{\mathrm{t}}=$ body weight at age $\mathrm{t}, \mathrm{BW}_{\mathrm{i}}=$ initial body weight and $\mathrm{K}$ and $\mathrm{I}=$ parameters of the Gompertz function. Daily gain of feeder and finishing pigs are 420 and $720 \mathrm{~g}$ in the base situation. Large groups with bedding (deep litter) slightly reduced growth performance (5\%) in the rearing and fattening stage. In contrast, larger groups with slatted flooring improved daily gain mainly due to better hygiene (all-in, all-out) and altered feeding systems. 14 days were needed to empty, clean and desinfect batches. Averaged daily feed intake of feeder and finishing pigs was within the range of 800 to $2140 \mathrm{~g}$ in the base situation (e.g. depending on daily gain).

In the default scenario postweaning mortality was $1 \%$, in the fattening period the mortality rate amounted for $3 \%$. Mortality of pigs took place in the half during the particular period. The weight of carcasses is related to live weight and killing out. Killing out was set to $79 \%$, the mean carcass weight corresponded to $90.9 \mathrm{~kg}$. In the present study, payment accounted only for lean meat percentage. Lean meat percentage is slightly negatively correlated with daily gain (SCHWERDTFEGER, 1992). Thus, lean meat is diminished using large groups size with slatted flooring.

\section{$2.4 \quad$ Economic factors}

The major economic factors are described in Table 3. Major cost components of the production chain were feed, investment, labour and other cost (e.g. energy, insurance, veterinarian, straw). The main differences between the alternate production systems concern the components investment, labour and other cost which is demonstrated at the fattening level: use of larger group size (40 pigs per group) with slatted flooring reduced cost compared to the default situation by $€ 51$ per place due to lower input for batch equipment. If pigs were kept on straw, cost for building (incl. repairs) declined by $€ 131$ (restricted straw: $0.2 \mathrm{~kg}$ per pig and day) or $€ 205$ (deep litter: $1.5 \mathrm{~kg}$ per pig and day).

Additionally to labour (increase by 31 or $41 \%$ ) straw raised production cost by mechanisation, purchase, storage and manure, whereas energy supply was diminished. In total other cost were enhanced by $€ 5.91$ (SM-ST) and $€ 11.4$ (LA-ST) per fattening pig. 
Table 3

Major economic factors for different stages and housing systems of the production chain (Ökonomische Parameter für die verschiedenen Stufen und Haltungsverfahren der Produktionskette)

\begin{tabular}{|c|c|c|}
\hline Stage / & Default & Alternative housing systems \\
\hline \multicolumn{3}{|l|}{ Farrowing stage } \\
\hline \multicolumn{3}{|l|}{ Feedprice (€/kg) } \\
\hline Lactation & 0.20 & \\
\hline Gestation/Mating & 0.16 & \\
\hline Investment (€/place) ${ }^{1)}$ & 1.529 & $\begin{array}{l}\text { G-ST(L): 466; G-S(G): -102; G-ST(G): -357; } \\
\text { G-S(M): -102; G-ST(M): -357 }\end{array}$ \\
\hline Labour (h) & $10.2^{2)}$ & $\begin{array}{l}\text { C-ST: 3; G-ST(L): 5; G-S(G): 0.04; } \\
\text { G-ST(G): 1.69;G-ST(M): } 1.01\end{array}$ \\
\hline Replacement (€/gilt) & 230 & \\
\hline Other Cost (€/sow) & 173 & $\begin{array}{l}\text { C-ST:17.2; G-ST(L): 17.2; G-ST(G): 46; } \\
\text { G-ST(M): } 28.3\end{array}$ \\
\hline \multicolumn{3}{|l|}{ Rearing stage } \\
\hline Feedprice $(€ / \mathrm{kg})$ & .28 & \\
\hline Investment (€/place) & 179 & LA-PS: -13; LA-ST: -56 \\
\hline Labour (min/day/pig) & 0.18 & LA-PS: 0.02; LS-ST: 0.05 \\
\hline Other cost (€/piglet) & 2.40 & LA-ST: 0.9 \\
\hline \multicolumn{3}{|l|}{ Fattening stage } \\
\hline Feedprice (€/kg) & 0.18 & \\
\hline Investment (€/place) & 409 & $\begin{array}{l}\text { LA-S: -51: SM-PS: -11; SM-ST: -131; } \\
\text { LA-ST: -205 }\end{array}$ \\
\hline Labour (min/day/pig) & 0.19 & SM-PS: 0.02; SM-ST: 0.06; LA-ST: 0.08 \\
\hline Other cost (€/pig) & 4.96 & SM-ST: 5.91; LA-ST: 11.4 \\
\hline \multicolumn{3}{|l|}{ Slaughtering stage } \\
\hline Meat price (€/kg carcass weight $)^{3)}$ & 1.28 & \\
\hline \multicolumn{3}{|l|}{ Devia. from the base $(€ / \%)$} \\
\hline $56-58$ & +0.015 & \\
\hline $52-55.9$ & -0.026 & \\
\hline $45-51.9$ & -0.041 & \\
\hline Labour $(€ / h)$ & 12.78 & \\
\hline
\end{tabular}

\section{$2.5 \quad$ Evaluation of the different production systems}

The different systems were evaluated by cost, welfare and $\mathrm{N}$ - and P-excretion.

Cost were considered as opportunity cost and were presented on an animal basis (fattening pig) at the different stages. Cost are partitioned in categories such as investment, feed and labour cost as well as other cost in each stage. Comparisons of the cumulative cost at the slaughtering level are adjusted for different prices due to e.g. lean percentages and pathological lesions.

A critical point is the judgement of welfare because welfare codes are difficult to 'define' in any objective sense (MCINERNEY, 1997). KNIERIM (1997 a, b) and ANDERSSON and SUNDRUM (1997) discussed ethological, physiological and pathological traits and methods like 'Tiergerechtheitsindex' in order to assess different housing systems. DEN OUDEN (1996) used the conjoint analysis to evaluate pig welfare perceptions of consumers and experts. BOLLMANN (1991) investigated the rank of environmental factors such as straw, social contact and movement using the operant technology and elasticity of demand based on own experiments and the study of MATTHEWS and LADEWIG (1991). The coeffcients increase in the order of straw (0.35), social contact (0.49) and movement (0.60) demonstrating the relative high importance of straw followed by contact and movement. According to this approach welfare were scaled from 0 (default situation) to 1 (e.g. straw with large group size). 
Farrowing and rearing/fattening stage had the same weight (1:1) for the whole production chain. Within each stage the relative importance of different production cycles depends on the duration of stay e.g. gestation period got a higher weight than the lactation period.

Calculation of the N-excretion is based on a model proposed by DOURMAD et al. (1992). The prediction model was developed for calculating the total amount of $\mathrm{N}$ excreted by the pig at different stages (gestation, mating, lactation, growing and finishing). $\mathrm{N}$ output was calculated on a daily basis between $\mathrm{N}$ intake and $\mathrm{N}$ retention. The mathematical model allows calculation of total $\mathrm{N}$ output from criteria easily accessible at the farm level (for more details, see DOURMAD et al., 1992). P balance was calculated as the difference between $\mathrm{P}$ intake and retention. In the present study, $\mathrm{N}$ - and P-excretion for feeder and fattening pigs focused on one universal feed (simulation model accounts also for two- and three-phase feeding). A precise adjustment of dietary protein to the specific requirements of the growing pigs was neglected. Thus differences in $\mathrm{N}$ - and P-excretion between systems are caused by different performance levels.

The optimisation (minimisation) of cost and welfare was performed with a linear programming model. Restrictions were introduced to get proper solutions e.g. if sows are kept in groups during lactation the group housing is necessary as well as in the mating and gestation period.

Table 4

Cost $(€)$, Nitrogen- (N, kg) and Phosphorus- (P, kg) excretion per slaughter-pig (Kosten, Stickstoff- (N) und Phosphor- (P) Ausscheidungen je Schlachtschwein)

\begin{tabular}{|c|c|c|c|}
\hline Stage & Unit & & $\%^{1)}$ \\
\hline $\begin{array}{l}\text { Farrowing } \\
\text { Feed } \\
\text { Investment } \\
\text { Labour } \\
\text { Other cost } \\
\text { N-Output } \\
\text { P-Output }\end{array}$ & $\begin{array}{l}€ \\
€ \\
€ \\
€ \\
\mathrm{~kg} \\
\mathrm{~kg}\end{array}$ & $\begin{array}{c}11.22 \\
8.08 \\
6.86 \\
11.47 \\
1.48 \\
0.28\end{array}$ & $\begin{array}{c}8.52 \\
6.13 \\
5.21 \\
8.71 \\
20.79 \\
23.33\end{array}$ \\
\hline $\begin{array}{l}\text { Rearing (feeder pig) } \\
\text { Feed } \\
\text { Investment } \\
\text { Labour } \\
\text { Other cost } \\
\left.\text { Transport }^{2}\right) \\
\text { N-Output } \\
\text { P-Output }\end{array}$ & $\begin{array}{l}€ \\
€ \\
€ \\
€ \\
€ \\
\mathrm{~kg} \\
\mathrm{~kg}\end{array}$ & $\begin{array}{l}10.78 \\
2.46 \\
1.93 \\
2.50 \\
1.58 \\
0.62 \\
0.13\end{array}$ & $\begin{array}{c}8.18 \\
1.87 \\
1.46 \\
1.90 \\
1.20 \\
8.71 \\
10.83\end{array}$ \\
\hline $\begin{array}{l}\text { Fattening } \\
\text { Feed } \\
\text { Investment } \\
\text { Labour } \\
\text { Other cost } \\
\text { Transport } \\
\text { N-Output } \\
\text { N-Output } \\
\text { P-Out }\end{array}$ & $\begin{array}{l}€ \\
€ \\
€ \\
€ \\
€ \\
\mathrm{~kg} \\
\mathrm{~kg}\end{array}$ & $\begin{array}{c}45.70 \\
14.92 \\
5.17 \\
4.96 \\
4.09 \\
5.02 \\
0.79 \\
\end{array}$ & $\begin{array}{c}34.69 \\
11.32 \\
3.93 \\
3.77 \\
3.11 \\
70.50 \\
65.83\end{array}$ \\
\hline $\begin{array}{l}\text { Total } \\
\text { Production cost } \\
\text { N-Output } \\
\text { P-Output }\end{array}$ & $\begin{array}{l}€ \\
\mathrm{~kg} \\
\mathrm{~kg}\end{array}$ & $\begin{array}{c}131.72 \\
7.12 \\
1.20\end{array}$ & $\begin{array}{l}100 \\
100 \\
100\end{array}$ \\
\hline
\end{tabular}


3. Results

3.1 Basic situation

Based on default values, sows produced 2.31 litters per year with 19.71 piglets weaned. 18.93 fattening pigs per sow and year were sold to slaughtering. Production cycles in the growing finishing period was limited to 2.87 .

Total production cost per slaughter-pig equalled $€ 131.72$ (Table 4). Feed cost were the major component with 51\%, followed by investment (19\%) and other cost (14\%). The fattening stage formed the largest part of total cost (57\%), the portions of the farrowing and rearing stages were $28 \%$ and $15 \%$ respectively.

In the growing and finishing period, feed cost and investment amounted to $€ 101.74$ (81\%). Feed (30\%) and other cost (31\%) were the major components in the farrowing stage. Other cost were e.g. veterinarian expenses (33\%), replacements (20\%) and water, energy, etc. (26\%). The farrowing stage is more labour-intensive compared to the more capital-intensive fattening stage.

The total amount of $\mathrm{N}$ and $\mathrm{P}$ excreted per head equalled $7.12 \mathrm{~kg}$ and $1.2 \mathrm{~kg}$. As shown in table 1 the main part is contributed by the fattening stage (71 and $66 \%$ for $\mathrm{N}$ - and P-Output respectively). N-excretion per fattening pig was calculated with $5.02 \mathrm{~kg} \mathrm{~N}$ and $0.79 \mathrm{~kg} \mathrm{P}$.

\subsection{Production systems and management tools}

Optimisation of production systems concerning cost implicated group housing of sows during gestation and at the fattening stage large groups (40 pigs) with slatted flooring (Table 5; see also appendix 1). Reduction of cost ( $€ 4.65)$ is determined by investment $(-10.9 \%)$, feed $(-3.4 \%)$ and labour $(-1.8 \%)$. Investment for gestation place per sow was reduced by $€ 102$,- (including repairs), cost of fattening place by $€ 51$,-. Labour in the gestation period was slightly increased due to 'educating' of young sows to the electronic feeding station. In total labour cost were diminished because number of production cycles (higher daily gain) enhanced which also explains the reduced feed cost per head. In addition, N-excretion per head was decreased by 360 g per head even though a lower meat percentage is opposite to an reduced $\mathrm{N}$-excretion.

Table 5

Cost $(€)$, Nitrogen- $(\mathrm{N}, \mathrm{g})$ and Phosphorus-(P, g) excretion per head dependent of the production and management systems (deviated from default) (Kosten, Stickstoff- $(\mathrm{N})$ und Phosphor-(P) Ausscheidungen je Schlachtschwein in Abhängigkeit von dem Produktions- und Managementverfahren (Abweichung von der Basissituation))

\begin{tabular}{|c|c|c|c|c|}
\hline & \multicolumn{2}{|c|}{ Production Systems } & \multicolumn{2}{|c|}{ Management } \\
\hline & \multirow{6}{*}{\multicolumn{2}{|c|}{$\begin{array}{l}\text { Crates slatted } \\
\text { Individual slatted } \\
\text { Group slatted } \\
\text { Small group, slatted } \\
\text { Large group, slatted }\end{array}$}} & \multirow{6}{*}{\multicolumn{2}{|c|}{ Default }} \\
\hline Lactation & & & & \\
\hline Mating & & & & \\
\hline Gestation & & & & \\
\hline Rearing & & & & \\
\hline Fattening & & & & \\
\hline Cost $(€ / \%)$ & $-4.65^{1)}$ & -3.5 & $-10.4^{1)}$ & -7.9 \\
\hline Feed & -2.30 & -3.4 & -4.71 & -7.0 \\
\hline Investment & -2.78 & -10.9 & -2.29 & -8.9 \\
\hline Labour & -0.25 & -1.8 & -1.59 & -11.4 \\
\hline Other Cost & -0.04 & -0.2 & -2.83 & -14.9 \\
\hline$N$-output $g$ & -360 & -5.1 & -936 & -13.2 \\
\hline P-output g & -62 & -5.2 & -167 & -14.0 \\
\hline
\end{tabular}

${ }^{1)}$ corrected for lower carcass revenue 
Table 5 shows comparatively the impact of a higher management level. Reduction of lactation length (from 4 to 3 weeks), number of rebreedings (12\%) and abortions (1.5\%) increased number of litters per sow and year (2.43). Piglets weaned per sow and year equalled 22.4. In the fattening stage 3.13 production cycles were realised. Feed conversion and daily gain was improved by roughly $10 \%$. Cumulative production cost per head were diminished by $€ 10.4$ (corrected for lower carcass revenue). Major part of reduction is caused by a decline in feed cost ( $€ 4.71$, other cost $€ 2.83$, and investment $€ 2.29$ ). Total $\mathrm{N}$ - and P-excretion was reduced to 6.18 and $1.03 \mathrm{~kg}$ per head due to the better performance which corresponds to a reduction of $13 \%$. The main part of the reduced excretion in absolute terms was caused by the fattening stage, followed by the farrowing and rearing stage.

Welfare

In Table 6 cost and $\mathrm{N}$ - and P-excretion are presented if welfare score is increased (as deviations from the base situation).

Table 6

Cost $(€)$, Nitrogen- $(\mathrm{N}, \mathrm{g})$ and Phosphorus $(\mathrm{P}, \mathrm{g})$-excretion per head dependent of welfare scale (deviated from default) (Kosten, Stickstoff- (N) und Phosphor-(P) Ausscheidungen je Schlachtschwein in Abhängigkeit von der Skalierung der Tiergerechtheit (Abweichung von der Basissituation)

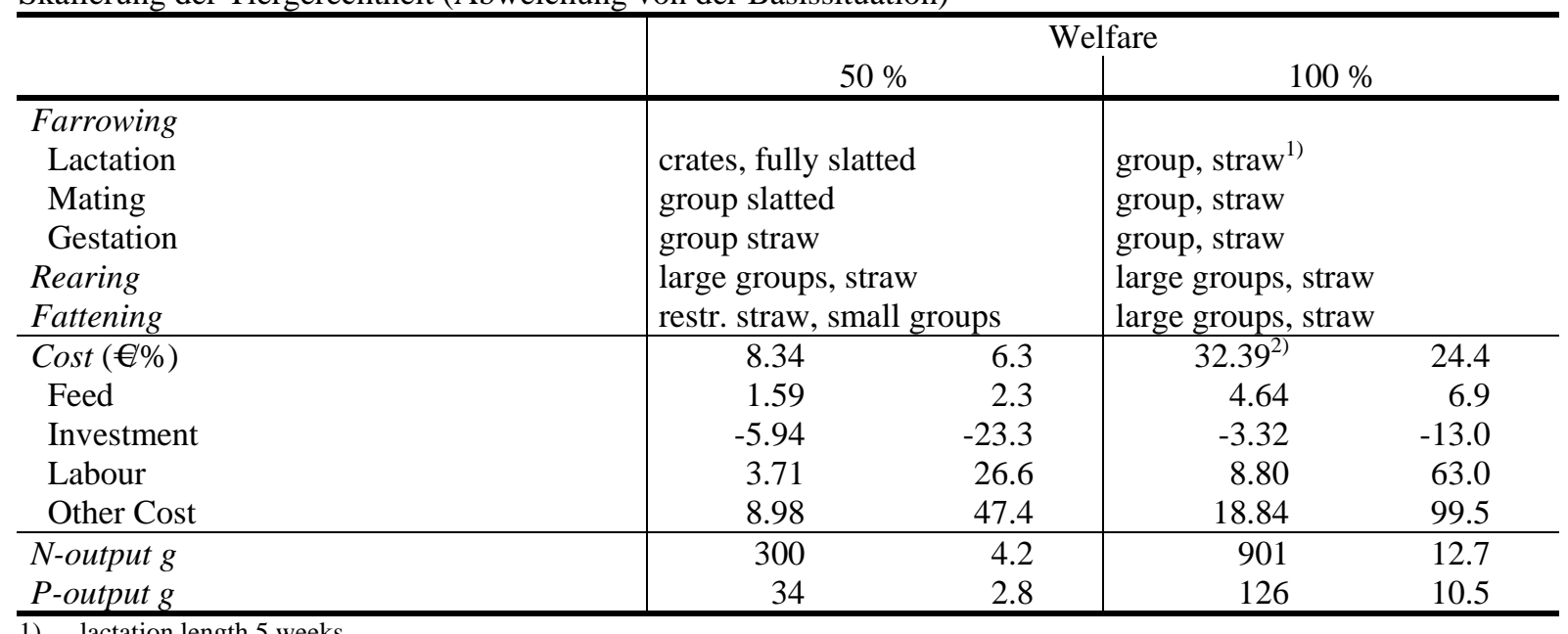

1) lactation length 5 weeks

2) corrected for meat percentage

If welfare scale of $50 \%$ in the whole production chain is supposed linear optimisation (minimising cost) provided crates (lactation) and group housing (mating) of sows on slatted flooring, during gestation groups with straw were recommended. In the rearing and fattening stage slatted flooring was replaced with straw (restricted). Enhanced welfare attributes incurred an increase in cost per head of $€ 8.34$ (6.3\%) due to labour (26.6\%) and other cost (47.4\%). Mechanisation, purchase of straw, manure etc. raised the production cost primarily in the fattening stage and gestation period. As expected the expense for building, repairing is reduced by 23.3\%. N- and P-excretion is slightly enhanced because number of slaughter pigs was diminshed caused by group housing in the mating area, higher mortality and lower daily gain during the rearing stage. A welfare level of $100 \%$ raised total cost by $24.4 \%$ (corrected for lower carcass revenue). Major components are the lactation period (39\%) and the fattening period (36\%). Keeping sows in groups during lactation (5 weeks) reduce the production cycles, induced a higher pig mortality which result in a lower number of piglet sold per sow 
and year (17.6). Group housing also incurred higher expenses of labour (straw, controlling) and investment because floor space per sow is enhanced. Additional cost in the fattening stage were caused by reduced daily gain (lower feed efficiency, reduced number of cycles), higher mortality rate and lower priced carcass value. Furthermore labour was increased by factor 1.63 and other cost by 2.1 . Due to the lower performance level in all stages $\mathrm{N}$ - and $\mathrm{P}$ - excretion enhanced to 8.02 and $1.32 \mathrm{~kg}$ per head.

\section{4.}

Discussion

In the base situation chain production cost per head was $€ 131.72$. Fattening stage accounted for $57 \%$ of the chain production cost followed by the farrowing (28\%) and rearing stages (15\%). Feed cost were the major component with 51\%. Investment and other cost accounted for $19 \%$ and $14 \%$ respectively. Similar results were obtained by DEN OUDEN (1996) who established the chain production cost of the farrowing stage (including rearing), fattening and slaughtering and processing stage under Dutch conditions. Total production cost were made up mainly of fattening (53\%) and farrowing (34\%). Slaughtering and processing cost accounted for 13\%. Feed cost were found to be the major cost component of the farm, followed by investment and other cost (farm level). N-excretion per fattening pig was calculated with $5.02 \mathrm{~kg} \mathrm{~N}$ and $0.79 \mathrm{~kg}$ P. JONGBLOED and LENIS (1993) and DOURMAD et al. (1992) reported lower $\mathrm{N}$-values. These differences may be partly due to different feeding strategies. The present study uses only one universal feed diet for feeder and fattening pigs. Assuming multiphase feeding N-excretion is reduced by $9.9 \%$ (4.52 kg, two-phase feeding) and 13.1 (4.36 kg; three-phase feeding) per pig, which yields comparable results described by JONGBLOED and LENIS (1993).

Selection of housing systems in the present study based on current distributions and trends and available information about biological performance and cost. Health or hygienic aspects were neglected since reliable data are scarce and health level strongly depends on management tools. Due to missing data systems like individual loose housing of sows during lactation and pasture were disregarded. A more detailed description and evaluation of attributes like additional illumination or total floor space in regard to judging welfare is objectively not possible, e.g. if $0.65 \mathrm{~m}^{2}$ is insufficient space for a fattening pig what is so good about $1 \mathrm{~m}^{2}$. Therefore the present study regards only a rough classification of housing systems which allows a realistic assignment of cost, welfare and performance.

The effect of optimising production systems on total chain production cost (and Nexcretion) for a given farm size was small with 3.5\% (and 5.1\%). Minimising cost requested group housing of sows during gestation and larger group size at the fattening stage. As expected, the differences between alternate systems (without bedding) could be neglected, e.g. partly slatted flooring caused slightly higher labour cost due to pen fouling. But these systems promoted animal welfare up to $25 \%$ compared to the default situation. The better evaluation of welfare arises from more social contacts and movement and from a clearer structuring of the pen. As expected higher management level had the major influence on total cost. Therefore systems with segregated stages in a vertical integrated production chain (e.g. Segregating Early Weaning; KRIETER, 2001) with professional management and controlling (e.g. Segregating Early Weaning; 
KRIETER, 2001) becomes more and more important for efficient pig production systems.

$\mathrm{N}$ - and P-excretion was calculated according to the model of DOURMAD et al. (1992). As expected more extensive systems (straw, prolonged lactation length) showed higher $\mathrm{N}$ - and P-excretion per fattening pig compared to the default situation due to the lower performance level. Similar results were shown by JONGBLOED and LENIS (1993). But further studies should also analyse the interactions between different housing systems and feeding strategies. N-excretion calculated with the model of DOURMAD et al (1992) depends on the performance level in the different stages (e.g. number piglets weaned, daily gain, meat percentage) whereas emission (e.g. $\mathrm{NH}_{3}$ ) is neglected. AARNINK and ELZING (1997) and KRÖTZ (1999) developed complex models to predict emission for different flooring (slatted, straw). But it is hardly possible to predict rates of emission for the different housing systems considered in the present study. In addition, storage and spreading of manure should included for a complete evaluation.

The evaluation of welfare rested upon the operant technology and elasticity of demand which allows a ranking of attributes without human perceptions. If the welfare level increased to $100 \%$ (straw, deep litter, without pasture) total chain production cost per head increased by $€ 32$ or 42 per head compared to the default or better management situation. GOURMELEN et al. (2000) reported values in the range from 3 to 14 ECU/100kg slaughter weight assuming different housing systems. DEN OUDEN (1996) calculated additional cost of US $\$ 40$ per head if pig welfare target equals $100 \%$ (consumer/expert evaluation). Assuming a welfare level of 50\% (present study) extra charges were increased by $€ 8.34$ per head. Sensitivity analysis demonstrate that these extra charges were very sensitive against labour and straw cost. Labour was set to $€$ 12.7 per hour which represent the lower limit. Straw was priced with $€ 5$ per $100 \mathrm{~kg}$ (purchase). If straw price and cost for mechanisation etc. decline the comparative ability of system with straw were upgraded. Provided that labour and straw are not limiting factors housing systems with restricted straw become more attractive for small sized fattening units. But in general more welfare friendly systems raise production cost and also cost of the food product. This may be acceptable if animal welfare is realised as a 'private good' which is ensured by safeguards of minimal standards by statutory means (MCINERNEY, 1997). Realisation of this fact leads to the situation that first each individual can decide to pay more or less according to its preference and secondly the necessary of administrative involvement is minimised.

\section{References}

AARNINK, A.J.A.; ELZING, A.:

Dynamic model for ammonia volatilization in housing with partially slatted floors, for fattening pigs. Live. Prod. Sci. 53 (1997), 153-169

ANDERSSON, R.; SUNDRUM, A.:

Bewertungsansätze. In: Beurteilung der Tiergerechtheit von Haltungssystemen. KTBL, Heft 377, 92-98, 1997

BOLLMANN, M.:

Quantitative Messung der Nachfrage nach Bewegung und Stroh beim Schwein unter Verwendung der operanten Konditionierungstechnik. Sonderheft 126, Landbauforschung Völkenrode, 1991

BRANDT, H.:

Konstruktion optimaler Selektionskriterien für Sauenvermehrungsbetriebe mit eigener Bestandsremontierung. Institut für Tierzucht und Haustiergenetik der Universität Göttingen, Diss., 1984 
CLAUS, H.; LENTFÖHR, G.; DEERBERG, K.H.:

Schweine-Report 2000. Betriebswirtschfatliche Mitteilungen der Landwirtschaftskammer SchleswigHolstein, Nr 534/535, 2000

DE BAEY-ERNSTEN, H.; ACHILLES, W.:

Alternativlösungen für den Wartestall. In: BauBriefe Landwirtschaft. Sauenhaltung und Ferkelaufzucht. Heft 37, 51-53, 1997

DE BAEY-ERNSTEN, H.:

Der Abferkelstall. In: BauBriefe Landwirtschaft. Sauenhaltung und Ferkelaufzucht. Heft 37, 54-58, 1997

DE BAEY-ERNSTEN, H.:

Gruppenhaltung von güsten und tragenden Sauen mit Abruffütterung. In: Gruppenhaltung von Sauen. Chancen rechnergestützter Verfahren. Kuratorium für Technik und Bauwesen in der Landwirtschaft, Heft 372, 21-53, 1996

DE VRIES, A.:

Selection for production and reproduction traits in pigs. Doctoral Thesis, Department of Animal Breeding, Wageningen Agricultural University, 1989

DEN OUDEN, M.:

Economic modelling of pork production-marketing chains. Doctoral Thesis, Department of Farm Management, Wageningen Agricultural University, 1996

DOURMAD, J.Y.; GUILLOU, D.; NOBLET, J.:

Development of a calculation model for predicting the amount of $\mathrm{N}$ excreted by the pig: effect of feeding, physiological stage and performance. Live. Prod. Sci. 31, (1992), 95-107

ELLERSIEK, H.H.:

Für 700,- DM einen Mastschweineplatz bauen. In: BauBriefe Landwirtschaft. Mastschweinehaltung. Heft 40, 96-99, 1999a

ELLERSIEK, H.H.:

Besonderheiten bei der Planung für Großgruppenhaltung. In: BauBriefe Landwirtschaft.

GERTKEN, G.: Mastschweinehaltung. Heft 40, 135-137, 1999b

Untersuchungen zur integrierten Gruppenhaltung von Sauen unter besonderer Berücksichtigung von Verhalten, Konstitution und Leistung. Schriftenreihe des Instituts für Tierzucht und Tierhaltung der Universität Kiel, Heft 70, 1992

GOURMELEN, C.; SALAÜN, Y.; ROUSSEAU, P.:

Economic incidence of possible future regulations regarding the welfare of intensively kept pigs on pig meat cost in France. $51^{\text {st }}$ Annual meeting of the European Association for Animal Production, Den Hague, The Netherlands, M6.4, 2000

HENDRIKS, PEDERSEN, B.K.; VERMEER, H.M.; WITTMANN, M.:

Pig housing systems in Europe: current distributions and trends. Pig News and Information, 19, 97N104N, 1998

HÖGES, J.L.; ACKERMANN, H.H.:

Alternativen in der Schweinehaltung. Eugen Ulmer GmbH \& Co., Stuttgart, 1998

JENSEN, K.H.; SORENSEN, L.S.; BERTELSEN, D.; PEDERSEN, A.R.; JOREGENSEN, E.; NIELSEN, N.P.;

VESTERGAARD, K.S.:

Management factors affecting activity and aggression in dynamic group housing systems with electronic sow feeding. A field trial. Anim. Sci., 71 (2000), 535-543

JONGBLOED, A.G.; LENIS, N.P.:

Excretion of nitrogen and some minerals in livestock. In: Nitrogen flow in pig production and environmental consequences. EAAP Publication No. 69, 22-36, 1993

KEMPKES, K.:

Das Deckzentrum. In: BauBriefe Landwirtschaft. Sauenhaltung und Ferkelaufzucht. Heft 37, 43-46, 1997

KNIERIM, U.:

Wissenschaftliche Konzepte zur Beurteilung der Tiergerechtheit im englischsprachigen Raum. In: Beurteilung der Tiergerechtheit von Haltungssystemen. KTBL, Heft 377, 31-39, 1997a

KNIERIM, U.:

Wissenschaftliche Untersuchungsmethoden zur Beurteilung der Tiergerechtheit. In: Beurteilung der Tiergerechtheit von Haltungssystemen. KTBL, Heft 377, 40-50, 1997b

KRIETER, J.:

Zuchtplanung beim Schwein. Schriftenreihe des Institutes für Tierzucht und Tierhaltung der Universität KRIETER, J. Kiel, Heft 81, 1994 
Computer simulation of cost and benefits of segregated early weaning (SEW) in a vertical pork production chain. Dtsch. Tierärztl. Wschr. 108 (2001), 281-320

KRIETER, J.; KALM, E.:

Growth, feed intake and mature size in Large White and Pietrain pigs. J. Anim. Breed. Genet. 106 KTBL: (1989), 300-311

Betriebsplanung 1999/2000. Daten für die Betriebsplanung. Kuratorium für Technik und Bauwesen in KRÖTZ, W.: der Landwirtschaft e.V., Darmstadt, 1999

Systemtechnische Behandlung der Ammoniakemission aus Festmist. Technische Universität München, Diss., 1999

MATTHEWS, L.R.; LADEWIG, J.:

Environmental requirements of pigs measured by behavioural demand functions. Zit. b. BOLLMANN, M., 1991

MCINERNEY, J.P.:

Economic aspects of the animal welfare issue. In: Application of quantitative methods in veterinary epidemiology. Wageningen Pers, 347-360, 1997

RANTZER, D.; SVENDSEN, J.:

Slatted versus solid floors in the dung area: comparison of pig production system (moved versus not moved) and effects on hygiene and pig performance, weaning to four weeks after weaning. Acta Agric. Scand., Sect. A., 51 (2001a), 175-183

RANTZER, D.; SVENDSEN, J.:

Slatted versus solid floors in the dung area of the farrowing pens: effects on hygiene and pig performance, birth to weaning.. Acta Agric. Scand., Sect. A., 51 (2001b), 167-174

SCHÄFER-MÜLLER, K.; STAMER, S.:

Gruppenhaltung in allen Reproduktionsstadien. In: Gruppenhaltung von Sauen. Chancen rechnergestützter Verfahren. Kuratorium für Technik und Bauwesen in der Landwirtschaft, Heft 372, 81-84, 1996

SCHWERDTFEGER, R.:

Schlachtkörperwert und Fleischbeschaffenheit von Mastendprodukten beim Schwein unter Berücksichtigung der Fettbeschaffenheit und Bauchbeurteilung. Schriftenreihe des Institutes für Tierzucht und Tierhaltung der Universität Kiel, Heft 69, 1992

TURNER, S.P.; EDWARDS, S.A.:

Housing in large groups reduces aggressiveness of growing pigs. $51^{\text {st }}$ Annual meeting of the European Association for Animal Production, Den Hague, The Netherlands, M6.8, 2000

VIT:

Trends, Fakten, Zahlen. Jahresbericht 2000. Vereinigte Informationssysteme Tierhaltung, Verden, 2000 WEBER, M.:

Der Wartestall. In: BauBriefe Landwirtschaft. Sauenhaltung und Ferkelaufzucht. Heft 37, 47-50, 1997

WOLTER, B.F.; ELLIS, M.; CURTIS, S.E.; AUGSPURGER, N.R.; HAMILTON, D.N.; PARR, E.N.; WEBEL, D.M.:

Effect of group size on pig performance in a wean-to-finish production system. J. Anim. Sci. 79 (2001), 1067-1073

Received: 2002-01-21

Accepted: 2002-04-16

Authors address

Prof. Dr. JOACHIM KRIETER

Institut für Tierzucht und Tierhaltung der

Christian-Albrechts-Universität zu Kiel

Olshausenstr. 40

D-24118 Kiel

Germany 
Appendix 1

Cost, Nitrogen- $(\mathrm{N})$ and Phosporous- (P) excretion per fattening pig for different housing systems (Kosten, Stickstoff- und Phosphor-Ausscheidungen je Schlachtschwein für verschiedene Haltungsverfahren)

\begin{tabular}{|c|c|c|c|c|c|c|c|c|c|c|c|c|c|c|c|c|c|c|c|c|}
\hline \multicolumn{10}{|c|}{ Sow } & \multirow{2}{*}{\multicolumn{3}{|c|}{ Rearing }} & \multirow{2}{*}{\multicolumn{5}{|c|}{ Fattening }} & \multirow{3}{*}{$\begin{array}{c}\text { Cost } \\
€\end{array}$} & \multirow{3}{*}{$\begin{array}{l}\mathrm{N} \\
\mathrm{kg}\end{array}$} & \multirow{3}{*}{$\begin{array}{l}\mathrm{P} \\
\mathrm{kg}\end{array}$} \\
\hline \multicolumn{4}{|c|}{ Lactation $^{1)}$} & \multicolumn{3}{|c|}{ Gestation } & \multicolumn{3}{|c|}{ Mating } & & & & & & & & & & & \\
\hline C-S & C-SP & G-ST4 & G-ST5 & I-S & G-S & G-ST & I-S & G-S & G-ST & SM-S & LA-PS & LA-ST & SM-S & LA-S & SM-PS & SM-ST & LA-ST & & & \\
\hline$\overline{\mathrm{BA}^{2)}}$ & & & & $\overline{\mathrm{BA}}$ & & & $\overline{\mathrm{BA}}$ & & & $\overline{B A}$ & & & $\overline{\mathrm{BA}}$ & & & & & 131.72 & 7.116 & 1.197 \\
\hline & - & & & $\mathrm{BA}$ & & & BA & & & BA & & & $\mathrm{BA}$ & & & & & 3.61 & 0 & 0 \\
\hline & & - & & $\mathrm{BA}$ & & & BA & & & $\mathrm{BA}$ & & & $\mathrm{BA}$ & & & & & 9.32 & 0.026 & 0.014 \\
\hline & & & - & BA & & & BA & & & BA & & & $\mathrm{BA}$ & & & & & 12.52 & 0.172 & 0.029 \\
\hline $\mathrm{BA}$ & & & & & - & & BA & & & BA & & & $\mathrm{BA}$ & & & & & -0.25 & 0 & 0 \\
\hline $\mathrm{BA}$ & & & & & & - & BA & & & BA & & & $\mathrm{BA}$ & & & & & 2.64 & 0 & 0 \\
\hline $\mathrm{BA}$ & & & & BA & & & & - & & BA & & & $\mathrm{BA}$ & & & & & 0.69 & 0.040 & 0.008 \\
\hline $\mathrm{BA}$ & & & & $\mathrm{BA}$ & & & & & ـ & $\mathrm{BA}$ & & & $\mathrm{BA}$ & & & & & 5.43 & 0.040 & 0.008 \\
\hline BA & & & & BA & & & BA & & & & - & & BA & & & & & 1.54 & 0.056 & 0.012 \\
\hline $\mathrm{BA}$ & & & & $\mathrm{BA}$ & & & $\mathrm{BA}$ & & & & & - & $\mathrm{BA}$ & & & & & 2.85 & 0.260 & 0.026 \\
\hline $\mathrm{BA}$ & & & & BA & & & BA & & & BA & & & & - & & & & -8.45 & -0.36 & -0.062 \\
\hline $\mathrm{BA}$ & & & & BA & & & BA & & & BA & & & & & ـ & & & -0.20 & 0 & 0 \\
\hline $\mathrm{BA}$ & & & & $\mathrm{BA}$ & & & BA & & & $\mathrm{BA}$ & & & & & & - & & 1.77 & 0 & 0 \\
\hline $\mathrm{BA}$ & & & & BA & & & $\mathrm{BA}$ & & & BA & & & & & & & - & 11.63 & 0.429 & 0.063 \\
\hline
\end{tabular}

1) G-ST4, G-ST5: lactation length 4 or 5 weeks; ${ }^{2}$ BA = default situation 